\title{
Social Media Usage Among Government Public Relations Practitioners of the Ministry of Finance of the Republic of Indonesia
}

\author{
Amalia Nugraha ${ }^{1, *}$ Ummi Salamah $^{2}$
}

\author{
${ }^{1}$ Universitas Indonesia \\ ${ }^{2}$ Universitas Indonesia \\ ${ }^{*}$ Corresponding author. Email: amalia.nugraha@gmail.com
}

\begin{abstract}
This paper presents the results of base-line research that aimed to analyze the usage of social media among 55 Government Public Relations (GPR) practitioners in the Ministry of Finance of the Republic of Indonesia. Social networks represent the potential for increased interaction between public administration, especially PR practitioners, and its stakeholders. The research used online survey methods and the results revealed that GPR practitioners in the Ministry of Finance mainly used Facebook and Instagram to interact only with "Group friends" and "Only to certain friends." This study provides a basic stepping stone for understanding the roles and uses of social media in the work of GPR practitioners and their organizational readiness.
\end{abstract}

Keywords: Social Media, Social Media Usage, Government Public Relations Practitioners, User Acceptance Model, Organizational Readiness

\section{INTRODUCTION}

Social media, defined as a two-way medium through which users construct personal identities through selfpresentation and dialog (Rettberg, 2009), has received extensive attention for the way it empowers the public relations function (Porter, Sweetser, \& Chung, 2009; Porter \& Sallot, 2005), provides tangible measurement metrics (Porter, Trammell, Chung, \& Kim, 2007) and facilitates environmental scanning (Kelleher \& Miller, 2006).

Social media offers numerous opportunities for public relations practitioners to interact with the public while adopting new forms of technology and integrating them into their everyday lives. These advances in technology have gone into widespread use among public relations practitioners and journalists (Eyrich, Padman, \& Sweetser, 2008; Lariscy, Avery, Sweetser, \& Howes, 2009; Porter et al., 2009). As more forms of social media emerge, it is beneficial for public relations practitioners to understand how to use these tools as they relate to their jobs. In particular, practitioners working for non-profit organizations can benefit from adopting social media to compensate for their often limited monetary resources
(Seltzer \& Mitrook, 2007; Waters, Burnett, Lamm, \& Lucas, 2009).

Social media is changing the way everyone, including journalists and public relations practitioners, communicate. Despite the prevalence of social media and those who use the attendant channels, the definition of what constitutes social media is still developing. Dykeman (2008) describes social media as a place for humans to use the internet and mobile-based tools for sharing and discussing information.

Based on the results of the Hootsuite survey, active social media user data in Indonesia as of January 2019 amounted to 150 million people (up 15\% or around $20 \%$ from 2018) (Hootsuite, 2019) and it can be concluded that social media is part of the daily lives of the Indonesian people, including government public relations (GPR).

Based on observations, within the GPR practitioners Ministry of the Republic of Indonesia, which is in the Ministry of Finance's Communication and Information Services Bureau of the Republic of Indonesia, especially users of social media, it seems that the minimum capability is relatively owned, especially regarding computer, internet and digital capabilities. With this 
minimum basic capability, GPR practitioners in the Ministry of Finance can carry out communication activities. From this activity, based on the phenomenon that arises, among the GPR practitioners of the Ministry of there are those who already have accounts on several social media and some who have not. Meanwhile, insofar as it can be observed, ownership of accounts is a precondition for the GPR practitioners at the Ministry to be able to access social media.

Although social media has attracted much attention from scholars in different fields (Eyrich et al., 2008; Wright \& Hinson, 2009), the role of social media in GPR has received little attention from scholars (Landsbergen, 2010). The potential use of social media for relationship management has been previously discussed in different contexts (Baird \& Parasnis, 2011; Waters \& Williams, 2011). In particular, its speed and flexibility in customizing usage of social media for two-way and multiway communication are identified as major advantages of social media use (Fletcher \& Lee, 2012). Despite a number of government organizations Similarly, this studies acknowledged that the usage of social media in GPR is not without unintended implications.

This study, among others, argues that social media could appear as a challenge that impedes GPR's goal. At present, there is a dearth of research examining the usage of social media among GPR practitioners in developing societies and how they affect GPR practices. In view of this gap, the current study has been conducted to address the following objectives: (i) to identify social media usage among GPR practitioners at work; (ii) to examine GPR practitioners' perception of the effectiveness of social media as a tool to engage with stakeholders; and (iii) to discover plausible implications imposed by social media on GPR roles and practices. The study also offers insight on the challenges that GPR practitioners experience in dealing with social media. The present study serves as a significant attempt to understand the implications of social media use on GPR roles and practices.

\section{LITERATURE REVIEW}

\subsection{Social Media}

The benefits of social media use are being recognized by organizations and public relations professionals across all industries. Online communication is becoming a necessity for organizations, and they are quickly incorporating this mode into their communication and operating plans (Taylor \& Doerfel, 2003).

Social media is seen to change the practice of public relations. This fact is expressed by Wright and Hinson (2010) who have examined the use of social media among public relations practitioners for five years. In the 5 th year of research (2010), it was found that $85 \%$ of public relations practitioners surveyed believed that new communication media had changed how organizations communicate, with a greater proportion of external communication than internal. Even so, traditional information media get more value than new media if judged from aspects of accuracy, credibility, honesty, and ethics.

Ron Jones explained that social media is an online media category where people talk, participate, share, network, and is defined by online activities. Most social media encourages users to discuss, provide feedback, vote, comment, and share information according to their interests. According to Jones, social media is more than just a two-way conversation, and more than one-way broadcasts like traditional media, social media is unique, embodying the idea of staying connected to sites, resources, and other people (Jones, 2009).

Social media is a media consisting of three parts, namely: the information infrastructure and tools used to produce and distribute media content; media content, which can be in the form of personal messages, news, ideas, and cultural products in digital form; then those who produce and consume media content in digital form are individuals, organizations, and industries (Howard \& Parks, 2012). According to Kotler and Keller (2009) social media is a medium used by consumers to share text, images, sound, and video information both with other people and companies and vice versa. This view is supported by a statement (Carr \& Hayes, 2015) where social media is seen as an internet-based medium that allows users the opportunity to interact and present themselves, either instantaneously or with a delay to as wide an audience as they wish, that drives the value of user-generated content and perceptions of interaction with other people. Social media is used productively by all areas of society, business, politics, media, advertising, the police, and emergency services. Social media has become the key to provoking thoughts, dialog, and actions around social issues.

\subsection{Government Public Relations}

GPR practitioners' - usually referred to as public affairs officials in the US and information or information officials or public relations officials in other countries are important links between the people and the government. The diversity of technical expertise, organizational goals and public activities of the functions of government public affairs is greater than the practice of traditional public relations and/or special. The culmination of the difference is that the public advocacy role that is exercised must master the art and good communication skills and must thoroughly understand the organization's culture, policies, practices, and constituents. Although public affairs may only be called the "word maker," its practitioners believe that their broad responsibilities and practices under the provisions of the law have made them entitled to bear the name of 
their own position. In a real sense, the purpose of public affairs itself is in accordance with the goals of democracy. Abundant and accurate information is available and is used by democratic governments to maintain responsive relationships with constituents, based on mutual understanding and continuous two-way communication (Cutlip, Center, \& Broom, 2000).

Another definition from Ardianto (2011) denotes a Public Relations Officer as a professional or professional communicator, appointed by a government institution with the task of serving information on public policies and services. A professional PR official is an intermediary or bridge between government institutions and the people or the community, both inside and outside. From these opinions, the authors conclude that a GPR official is a person who is professional in the field of connecting the state and society, appointed by government institutions to provide information to the public.

Public relations discourse shapes relationships, dependencies, and societal expectations. As communication technologies grow, larger and more diverse networks emerge, creating network ecologies. The study of relationships within network ecologies is timely, given the inter-connectedness in the public sphere. Network ecology embodies a macro understanding of the many, diverse ego networks of organizations comprising the public sphere. Network (community) ecology examines the evolution of organizational populations by looking at the communities in which they operate (Monge \& Poole, 2008).

\subsection{User Acceptance Models}

The presence of innovation based on online technologies has expanded dramatically. Internet-related communication technologies let corporations communicate with their publics effectively and efficiently. Research on individual acceptance of new technologies is generally consistent with individual reactions to a new technology. There is a variety of theoretical perspectives, and many studies have addressed individual adoption of new technologies. Most of them have studied how and why individuals adopt new information technologies (Venkatesh, Morris, Davis, \& Davis, 2003).

Within this broad research perspective, the focus is mostly on explaining acceptance and adoption of new technologies and basically stems from the "uses and gratifications" perspective. Information technology acceptance research has yielded many models. Venkatesh et al. (2003) reviewed eight models, which employed technology adoption models in their studies. According to their study, there are two main perceptions, which are the most influential predictors of adoption. These perceptions have been determined to have significant impact on adoption: "Perceived Usefulness and Perceived Ease of Use" (Hong \& Tam, 2006).

Survey research (Choi, Watt, Dekkers, \& Park, 2004) on internet users is limited to describing who the users are and what they do on the internet medium. Further attention, such as on the causes of users using the internet medium does not feature in the corpus of work. To fill the shortcomings, Choi et al. tried to examine the use of the internet in terms of the way by exploring the motives of internet users in online activities.

This research alone not attempts what Choi et al. have done in examining the phenomenon of internet use. In addition, this study will also examine the phenomenon of internet use differently from that done by Choi et al. which is focused on the phenomenon of communication of internet users through social media as part of the internet. The communication phenomenon is related to the pattern of GPR activities in communicating through social media. The concept of use in the uses and gratification approach signifies activity in the audience of media users. Related to this, Choi et al. noted that the active audience approach is consistent with the nature of the internet audience, which has vast choices of content and wide latitude in usage patterns. Meanwhile, audience activities themselves mean that members of the audience are directing themselves to the communication process (Levy \& Windhal, 1985).

The activities of the audience are then divided into two dimensions. First, the audience orientation dimension consists of three levels, namely selectivity, involvement and utilization, while the dimensions of the second sequence of communication distinguish activities based on the time of occurrence: before, during, and after media exposure. Therefore, observing the activities of audiences in relation to the media, broadly speaking can be done in two ways, first according to the orientation dimension and second according to the dimensions of the communication sequence (Levy \& Windhal, 1985).

As this paper's literature review indicates, many have studied or reported on the huge impact social media has on the practice of public relations. What are missing in this prior research, however, are studies examining how public relations practitioners are using the social media. The international survey of public relations practitioners reported in this article appears to be the world's first extensive examination of how social media is being implemented in public relations practice. In addition to measuring how social media is being employed in the practice of public relations, this study also explores actual social media use by individual public relations practitioners. 


\section{RESEARCH METHODOLOGY}

This research uses the positivistic paradigm and online survey methods as data collection techniques. An online survey was conducted among 55 GPR practitioners from the Communication and Information Services Bureau at the Ministry of Finance of the Republic of Indonesia

Two hypotheses were tested in this study:

RQ1: To what extent do GPR practitioners use social media to reach their publics?

RQ2: What is the nature of social media use (reasons for use, frequency of use, extent of monitoring, age of account, and content in social media) among GPR practitioners?

Data collection was done using an online questionnaire and the collected data then processed by computer using the SPSS application. The output of SPSS data is the main data source for analysis (descriptive) and interpretation.

\section{RESULTS AND ANALYSIS}

\subsection{To What Extent do GPR Practitioners Use Social Media to Reach Their Publics}

Respondents in this study were GPR practitioners at the Ministry of Finance Republic of Indonesia Communication and Information Services Bureau. Online questionnaires distributed to all respondents amounted to a total population of 102 people. From that number, 53 people were received who responded or filled out answers to questions from the questionnaire distributed.

In Table I, the researcher wanted respondents' data regarding ownership of social media accounts. The amounts and percentages are as follows:

Table 1. Respondents based on social media ownership (Source: Data is processed by Researcher)

\begin{tabular}{|c|c|c|c|c|c|c|}
\hline \multirow{3}{*}{$\begin{array}{c}\text { Brand of } \\
\text { Social Media }\end{array}$} & \multicolumn{4}{|c|}{ Ownership } & \multirow{2}{*}{\multicolumn{2}{|c|}{ Total }} \\
\hline & \multicolumn{2}{|c|}{ Yes } & \multicolumn{2}{|c|}{ No } & & \\
\hline & $f$ & $\%$ & $f$ & $\%$ & $f$ & $\%$ \\
\hline Facebook & 53 & 100.0 & 0 & 0 & 53 & 100.0 \\
\hline Instagram & 50 & 94.3 & 3 & 5.7 & 53 & 100.0 \\
\hline Twitter & 48 & 90.6 & 5 & 9.4 & 53 & 100.0 \\
\hline Linkedln & 33 & 62.3 & 20 & 37.7 & 53 & 100.0 \\
\hline YouTube & 30 & 56.6 & 23 & 43.4 & 53 & 100.0 \\
\hline
\end{tabular}

\subsection{Description of the Nature of Social Media Usage Among GPR Practitioners}

\subsubsection{Respondents Based On Various Online Activities on Social Media}

Related to the phenomenon of activity habits when online through this social networking site, there are nine types of online activity being explored. Based on the results of the study, out of the nine types of activity mentioned above, there were six that appeared to be predominantly conducted by respondents when they were online (see Table II). The proportion of respondents who carried out these activities ranged from $64.2 \%-86.8 \%$.

Table 2. Respondents based on types of online activities on social media (Source: Data is processed by

Researcher)

\begin{tabular}{|c|c|c|c|c|c|c|c|}
\hline \multirow{2}{*}{ No } & \multirow{2}{*}{$\begin{array}{c}\text { Online } \\
\text { Activities }\end{array}$} & \multicolumn{2}{|c|}{ Yes } & \multicolumn{2}{|c|}{ No } & \multicolumn{2}{|c|}{ Total } \\
\hline & & $f$ & $\%$ & $f$ & $\%$ & $f$ & $\%$ \\
\hline 1 & $\begin{array}{l}\text { Uploading } \\
\text { photos or } \\
\text { videos of } \\
\text { yourself }\end{array}$ & 45 & 84.9 & 8 & 15.1 & 53 & $\begin{array}{c}100 . \\
0\end{array}$ \\
\hline 2 & $\begin{array}{l}\text { Uploading } \\
\text { and } \\
\text { downloadin } \\
\text { g other's } \\
\text { people's } \\
\text { photos or } \\
\text { videos }\end{array}$ & 24 & 45.3 & 29 & 54.7 & 53 & $\begin{array}{c}100 . \\
0\end{array}$ \\
\hline 3 & $\begin{array}{l}\text { Inviting or } \\
\text { accepting } \\
\text { other } \\
\text { people to } \\
\text { become } \\
\text { friends }\end{array}$ & 46 & 86.8 & 7 & 13.2 & 53 & $\begin{array}{c}100 . \\
0\end{array}$ \\
\hline 4 & $\begin{array}{l}\text { Looking for } \\
\text { old friends }\end{array}$ & 43 & 81.1 & 10 & 18.9 & 53 & $\begin{array}{c}100 . \\
0\end{array}$ \\
\hline 5 & $\begin{array}{l}\text { Expanding } \\
\text { network of } \\
\text { friends who } \\
\text { can support } \\
\text { work }\end{array}$ & 42 & 79.2 & 11 & 20.8 & 53 & $\begin{array}{c}100 . \\
0\end{array}$ \\
\hline 6 & $\begin{array}{l}\text { Expressing } \\
\text { unspoken } \\
\text { feeling, } \\
\text { criticism, }\end{array}$ & 25 & 47.2 & 28 & 52.8 & 53 & $\begin{array}{c}100 . \\
0\end{array}$ \\
\hline
\end{tabular}




\begin{tabular}{|c|c|c|c|c|c|c|c|}
\hline \multirow{2}{*}{ No } & \multirow{2}{*}{$\begin{array}{c}\text { Online } \\
\text { Activities }\end{array}$} & \multicolumn{2}{|c|}{ Yes } & \multicolumn{2}{|c|}{ No } & \multicolumn{2}{|c|}{ Total } \\
\hline & & $f$ & $\%$ & $f$ & $\%$ & $f$ & $\%$ \\
\hline & $\begin{array}{l}\text { and } \\
\text { suggestion }\end{array}$ & & & & & & \\
\hline 7 & $\begin{array}{l}\text { Commentin } \\
\text { g on other } \\
\text { people's } \\
\text { statements } \\
\text { on social } \\
\text { media }\end{array}$ & 34 & 64.2 & 19 & 35.8 & 53 & $\begin{array}{c}100 . \\
0\end{array}$ \\
\hline 8 & $\begin{array}{l}\text { Expressing } \\
\text { aspirations } \\
\text { or ideas in } \\
\text { order to } \\
\text { inspire } \\
\text { friends on } \\
\text { social } \\
\text { media }\end{array}$ & 38 & 71.7 & 15 & 28.3 & 53 & $\begin{array}{c}100 . \\
0\end{array}$ \\
\hline 9 & $\begin{array}{l}\text { Offering } \\
\text { goods to } \\
\text { friends on } \\
\text { social } \\
\text { media }\end{array}$ & 21 & 39.6 & 32 & 60.4 & 53 & $\begin{array}{c}100 . \\
0\end{array}$ \\
\hline
\end{tabular}

If the activity referred to is ranked, the sequence becomes as described in Table III as follows:

Table 3. Respondents' rankings based various online activities on social media (Source: Data is processed by Researcher)

\begin{tabular}{|c|l|c|}
\hline No & \multicolumn{1}{|c|}{ Online Activities } & $\begin{array}{c}\text { Rank } \\
\text { (\%) }\end{array}$ \\
\hline 1 & $\begin{array}{l}\text { Inviting or accepting other people to } \\
\text { become friends }\end{array}$ & 86.8 \\
\hline 2 & Uploading photos or videos of yourself & 84.9 \\
\hline 3 & Looking for old friends & 81.1 \\
\hline 4 & $\begin{array}{l}\text { Expanding network of friends who can } \\
\text { support work }\end{array}$ & 79.2 \\
\hline 5 & $\begin{array}{l}\text { Expressing aspirations or ideas in order } \\
\text { to inspire friends on social media }\end{array}$ & 71.7 \\
\hline 6 & $\begin{array}{l}\text { Commenting on other people's } \\
\text { statements on social media }\end{array}$ & 64.2 \\
\hline
\end{tabular}

$f=$ frequency

\subsubsection{Respondents' Direction or Orientation on Social Media}

This sub-chapter will explain the phenomenon of the direction or orientation of communication activities commonly carried out by GPR practitioners of the Ministry of Finance through its social media. The results of the study show that, in fact, four communication direction activities were found when the respondents carried out activities, namely, to everyone, only to certain friends, group friends, and to someone.

From a number of types of communication targets, the research findings indicate that the party who was the target of the communication turned out to be dominant to group friends, as much as $79.2 \%$ of respondents. Then the second place was $69.8 \%$ of respondents answered the direction or orientation only to certain friends.

Respondents' direction or orientation on social media to everyone was $58.5 \%$ and the direction or orientation of the respondents on social media to someone reaches $54.7 \%$. More information about the distribution of data concerning this phenomenon is presented in Table IV below.

Table 4. Respondents' direction or orientation on social media (Source: Data is processed by Researcher)

\begin{tabular}{|c|l|c|c|c|c|c|c|}
\hline \multirow{2}{*}{ No } & $\begin{array}{c}\text { Direction/ } \\
\text { Orientation of } \\
\text { Communication } \\
\text { Activities }\end{array}$ & $\boldsymbol{f}$ & $\%$ & $\boldsymbol{f}$ & $\%$ & $\boldsymbol{f}$ & $\%$ \\
\cline { 5 - 9 } & To everyone & 31 & 58.5 & 22 & 41.5 & 53 & 100.0 \\
\hline 2 & $\begin{array}{l}\text { Only to certain } \\
\text { friends }\end{array}$ & 37 & 69.8 & 16 & 30.2 & 53 & 100.0 \\
\hline 3 & Group friends & 42 & 79.2 & 11 & 20.8 & 53 & 100.0 \\
\hline 4 & To someone & 29 & 54.7 & 24 & 45.3 & 53 & 100.0 \\
\hline
\end{tabular}

\subsubsection{Frequency of Respondents' Use of Social Media}

The findings on the description of the frequency of respondents conducting various types of activity related to social media beforehand are presented in Table $\mathrm{V}$. From the data distribution pattern in Table V., it is known that the respondents tend to respond more often with "Never" on accessing the types of activity in question. The proportion ranges from $13.2 \%-41.5 \%$ who are "Looking for old friends" and "Offering goods to friends on social media."

Then, from the types of activity that have been accessed, the number of respondents having access is quite large, and the findings show that their frequency of access to these types of activity tends to be more "Rare." For example, "Uploading photos or videos of yourself" come to $66 \%$, "Expressing unspoken feeling, criticism, or suggestions" comes to $58.5 \%$, and "Looking for old friends" comes to $50.9 \%$. 
Quite a small number of respondents (47.2\%) "Often" access social media, namely respondents with activities of "Expanding network of friends who can support work," while the activities "Expressing aspirations or ideas in order to inspire friends on social media" and "Inviting or accepting other people to be friends" have the same value $(45.3 \%)$.

While the type of activity "Expanding network of friends who can support work" is a "Very Often" type of activity carried out by a number of respondents even though in a relatively small proportion at $9.4 \%$ and "Offering goods to friends on social media" makes up $5.7 \%$.

Table 5. Frequency of respondents' use of social media (Source: Data is processed by Researcher)

\begin{tabular}{|c|c|c|c|c|c|c|c|c|c|c|c|}
\hline \multirow{2}{*}{$\begin{array}{l}N \\
0\end{array}$} & \multirow{2}{*}{$\begin{array}{c}\text { Online } \\
\text { Activities }\end{array}$} & \multicolumn{2}{|c|}{$\begin{array}{l}\text { Very } \\
\text { often }\end{array}$} & \multicolumn{2}{|c|}{ Often } & \multicolumn{2}{|c|}{ Rave } & \multicolumn{2}{|c|}{ Never } & \multicolumn{2}{|c|}{ Total } \\
\hline & & $f$ & $\%$ & $f$ & $\%$ & $f$ & $\%$ & $f$ & $\%$ & $f$ & $\%$ \\
\hline 1 & $\begin{array}{l}\text { Uploading } \\
\text { photos or videos } \\
\text { of yoursalf }\end{array}$ & 2 & 3.8 & 16 & $\begin{array}{c}30 . \\
2\end{array}$ & 35 & 66 & 0 & 0 & 53 & 100.0 \\
\hline 2 & $\begin{array}{l}\text { Uploading and } \\
\text { dornloading } \\
\text { other's people } \\
\text { photos or vidaos }\end{array}$ & 0 & 0 & 13 & $\begin{array}{c}24 . \\
5\end{array}$ & 24 & $\begin{array}{c}45 . \\
3\end{array}$ & 16 & $\begin{array}{c}30 . \\
2\end{array}$ & 53 & 100.0 \\
\hline 3 & $\begin{array}{l}\text { Inviting or } \\
\text { accepting other } \\
\text { paople becarme } \\
\text { friends }\end{array}$ & 3 & 5.7 & 24 & $\begin{array}{c}45 . \\
3\end{array}$ & 25 & $\begin{array}{c}47 . \\
2\end{array}$ & 1 & 1.9 & 53 & 100.0 \\
\hline 4 & $\begin{array}{l}\text { Looking for old } \\
\text { friends }\end{array}$ & 1 & 1.9 & 18 & 34 & 27 & $\begin{array}{c}50 . \\
9\end{array}$ & 7 & $\begin{array}{c}13 . \\
2\end{array}$ & 53 & 100.0 \\
\hline 5 & $\begin{array}{l}\text { Expanding } \\
\text { natworkik of } \\
\text { friends who can } \\
\text { support work }\end{array}$ & 5 & 9.4 & 25 & $\begin{array}{c}47 . \\
2\end{array}$ & 18 & 34 & 5 & 9.4 & 53 & 100.0 \\
\hline 6 & $\begin{array}{l}\text { Exprassing } \\
\text { unspolsen } \\
\text { fealing, critics, } \\
\text { and suggeastion }\end{array}$ & 0 & 0 & 13 & $\begin{array}{c}24 . \\
5\end{array}$ & 31 & $\begin{array}{c}58 . \\
5\end{array}$ & 9 & 17 & 53 & 100.0 \\
\hline 7 & $\begin{array}{l}\text { Commenting on } \\
\text { other people's } \\
\text { statements on } \\
\text { socisl medis }\end{array}$ & 2 & 3.8 & 17 & $\begin{array}{c}32 . \\
1\end{array}$ & 27 & $\begin{array}{c}50 . \\
9\end{array}$ & 7 & $\frac{13 .}{2}$ & 53 & 100.0 \\
\hline 8 & $\begin{array}{l}\text { Expressing } \\
\text { aspirations or } \\
\text { idess in order to } \\
\text { inspire friends } \\
\text { on socisl media }\end{array}$ & 3 & 5.7 & 24 & $\begin{array}{c}45 . \\
3\end{array}$ & 21 & $\begin{array}{c}39 . \\
6\end{array}$ & 5 & 9.4 & 53 & 100.0 \\
\hline 9 & $\begin{array}{l}\text { Offering goods } \\
\text { to friends on } \\
\text { social media }\end{array}$ & 3 & 5.7 & 9 & 17 & 19 & $\begin{array}{l}35 . \\
8\end{array}$ & 22 & $\begin{array}{c}41 . \\
5\end{array}$ & 53 & 100.0 \\
\hline
\end{tabular}

$f=$ frequency

\section{DISCUSSION AND CONCLUSION}

This study is base-line research to answer the phenomenon of social media usage among GPR practitioners in the Ministry of Finance of the Republic of Indonesia.

The various types of activities referred to: "Inviting or accepting other people becoming friends" (86.8\%); "Uploading photos or videos of yourself" (84.9\%); "Looking for old friends" (81.1\%); "Expanding network of friends who can support work" (79.2\%); "Expressing aspirations in orders to inspire friends on social media" (71.7\%); and "Commenting on other people 's statements on social media" (64.2\%) including the types of activity that are commonly practiced by respondents, whereas for other types of activity, such as "Expressing unspoken feeling, criticism, and suggestion" among others, the proportion is still $<50 \%$.
The phenomenon of the dominance of a large number of these types of activity reflects attitudes that tend to be "personal interest" and "business interest" attitudes that have not been fully implemented by respondents. In relation to the phenomenon of Respondents' Communication Direction or Orientation through social media, the findings indicate that the respondents' usual target of communication is more in proportion, which directs "Group friends" and "Only to certain friends," it can be concluded that they do not assume their role as PR practitioners while using social media.

Concerning the question of the Frequency of Communication of Respondents through social media, it is known that there are more respondents who tend to "never" access the types of activity with proportions ranging from $13.2 \%-41.5 \%$, namely the type of activity "Looking for old friends" and "Offering goods to friends on social media." Furthermore, from the types of activity that have been accessed, the number of respondents having access is relatively large, showing that the frequency of their access to these types of activity tends to be more "rare." For example, the types of activity "Uploading photos or videos of yourself," "Expressing feelings, criticism, suggestions," and "Looking for old friends." While the number of respondents who are slightly more numerous are "Frequently" accessing, namely the respondents accessing "Expanding network of friends who can support work," while the type of "Expanding network of friends who can support work" activity is a type of activity that is "very often" carried out by a number of respondents even though there are not many proportions. With findings that reflect the diversity of respondents' activities (in the dimensions of the Variety of Online Activities; Direction or Orientation of Communication Activities and Frequency of Communication Activities) in accessing social media beforehand, it may be a picture that is relevant to what is assumed by Levy and Windahl (1985).

In the assumption of the uses and gratification theory, the occurrence of a variety of self-activities also includes a form of reflection of the variety of individual efforts in meeting their needs through the use of media, namely "how individuals use mass communication to their needs.”(Levy \& Windahl, 1985). However, according to the assumptions in the uses and gratification theory model, the cause is related to antecedent variables such as motives, individual characteristics and the like. Therefore, for future research, it is necessary to include the antecedent variable in research as a guide for the acquisition of empirical data for research.

\section{REFERENCES}

[1] Ardianto, E. (2011). Handbook of Public Relations: Pengantar Komprehensif. Bandung: Simbiosa Rekatama Media. 
[2] Baird, C. H., \& Parasnis, G. (2011). From social media to social customer relationship management. Strategy and Leadership, 39(5), 30-37. DOI: https://doi.org/10.1108/10878571111161507

[3] Carr, C. T., \& Hayes, R. A. (2015). Social media: Defining, developing, and divining. Atlantic Journal of Communication, 23(1), 46-65. DOI: https://doi.org/10.1080/15456870.2015.972282

[4] Choi, J., Watt, J., Dekkers, A., \& Park, S.-H. (2004). Motives of Internet Uses: Crosscultural Perspectives-the US, the Netherlands, and South Korea. The Annual Meeting of the International Communication Association. Los Angeles. Retrieved from https://surfsharekit.nl/publiek/fontys/3843a8406345-4203-a5e6-faa52873d8ba

[5] Cutlip, S. M., Center, A. H., \& Broom, G. M. (2000). Effective Public Relations (8th ed.). New Jersey: Prentice Hall.

[6] Dykeman, D. (2008). How do you define social media? Retrieved August 11, 2019, from http://broadcasting-brain.com/2008/02/09/how-doyoudefine-social-media/

[7] Eyrich, N., Padman, M. L., \& Sweetser, K. D. (2008). PR practitioners' use of social media tools and communication technology. Public Relations Review, 34(4), 412-414. DOI: https://doi.org/10.1016/j.pubrev.2008.09.010

[8] Fletcher, A., \& Lee, M. J. (2012). Current social media uses and evaluations in American museums. Museum Management and Curatorship, 27(5), 505521.

DOI: https://doi.org/10.1080/09647775.2012.738136

[9] Hong, S. -J., \& Tam, K. Y. (2006). Understanding the adoption of multipurpose information appliances: The case of mobile data services. Information System Research, 17(2), 105-196. DOI: https://doi.org/10.1287/isre.1060.0088

[10] Hootsuite. (2019). Digital 2019: Indonesia. Global Digital Insights. Hootsuite. DOI: https://doi.org/https://datareportal.com/reports/digit al-2019-indonesia

[11] Howard, P. N., \& Parks, M. R. (2012). Social media and political change: capacity, constraint, and consequence. Journal of Communication, 62(2), 359-362. DOI: https://doi.org/10.1111/j.1460-2466.2012.01626.x

[12] Jones, R. (2009). Social media marketing 101. Retrieved June 20, 2019, from https://searchenginewatch.com/sew/opinion/206441 3/social-media-marketing-101-part

[13] Kelleher, T., \& Miller, B. M. (2006). Organizational blogs and the human voice: Relational strategies and relational outcomes. Journal of Computer-Mediated Communication, 11(2), 395-414. DOI: https://doi.org/10.1111/j.1083-6101.2006.00019.x

[14] Kotler, P., \& Keller, K. L. (2009). Manajemen Pemasaran Jilid 1. Terjemahan Bob Sabran, Ed. (13th ed.). Jakarta: Erlangga.

[15] Landsbergen, D. (2010). Government as part of the revolution. Electronic Journal of E-Government, 8(2), 135-147. Retrieved from file://C:/Users/208232184/Downloads/ejegvolume8-issue2-article204.pdf

[16] Lariscy, R. W., Avery, E. J., Sweetser, K. D., \& Howes, P. (2009). An examination of the role of online social media in journalists' source mix. Public Relations Review, 35(3), 314-316. DOI: https://doi.org/10.1016/j.pubrev.2009.05.008

[17] Levy, M., \& Windahl, S. (1984). The Concept of Audience Activity. In Media Gratifications Research. SAGE, 11(1), 51-78. DOI: https://doi.org/10.1177/009365084011001003

[18] Monge, P., \& Poole, M. S. (2008). The Evolution of Organizational Communication. Journal of Communication, 58(4), 679-692. DOI: https://doi.org/10.1111/j.1460-2466.2008.00408.x

[19] Porter, L., Sweetser, K., \& Chung, D. (2009). The blogosphere and public relations: Investigating practitioners' roles and blog use. Journal of Communication Management, 13(3), 250-267. DOI: https://doi.org/10.1108/13632540910976699

[20] Porter, L. V., \& Sallot, L. M. (2005). Web power: A survey of practitioners' World Wide Web use and their perceptions of its effects on their decisionmaking power. Public Relations Review, 31(1), 111-119.

DOI: https://doi.org/10.1016/j.pubrev.2004.11.014

[21] Porter, L. V., Trammell, K. D. S., Chung, D., \& Kim, E. (2007). Blog power: Examining the effects of practitioner blog use on power in public relations. Public Relations Review, 33(1), 92-95. DOI: https://doi.org/10.1016/j.pubrev.2006.11.018

[22] Rettberg, J. W. (2009). "Freshly generated for you, and Barack Obama": How social media represent your life. European Journal of Communication, 24(4), 451-466. DOI: https://doi.org/10.1177/0267323109345715

[23] Seltzer, T., \& Mitrook, M. A. (2007). The dialogic 
potential of weblogs in relationship building. Public Relations Review, 33(2), 227-229. DOI: https://doi.org/10.1016/j.pubrev.2007.02.011

[24] Venkatesh, V., Morris, M., Davis, G., \& Davis, F. (2003). User acceptance of information technology: Toward a unified view. MIS Quarterly, 27(3), 425478.

[25] Waters, R. D., Burnett, E., Lamm, A., \& Lucas, J. (2009). Engaging stakeholders through social networking: How nonprofit organizations are using Facebook. Public Relations Review, 35(2), 102106.

DOI: https://doi.org/10.1016/j.pubrev.2009.01.006

[26] Wright, D. K., \& Hinson, M. D. (2009). Examining how public relations practitioners actually are using social media. Public Relations Journal, 3(3), 1-33.
[27] Wright, D. K., \& Hinson, M. D. (2010). How new communications media are being used in public relations: A longitudinal analysis. Public Relations Journal, 4(3), 1-27. Retrieved from http://apps.prsa.org/searchresults/download/6D040202/0/An_Analysis_of_New_Communications_ Media_Use_in_Pub

[28] Waters, R. D., \& Williams, J. M. (2011). Squawking, tweeting, cooing, and hooting: analyzing the communication patterns of government agencies on Twitter. Journal of Public Affairs, 11(4), 353-363. DOI: https://doi.org/10.1002/pa 